SHORT COMMUNICATION

\title{
PROBLEMS ASSOCIATED WITH THE ESTIMATION OF CYANIDE IN RUBBER SEED KERNEL
}

G. V. MALLIKA, E. R. JANSZ, NIRMALA M. PIERIS

Ceylon Institute of Scientific and Industrial Research, P.O. Bax 787, Colombo.

AND

\section{A. M. ABEYSEKERA}

Department of Chemistry, University of Sri Jayewardenepura, Nugegoda.

(Date of receipt : 11 February 1993)

(Date of acceptance : 16 April 1993)

Key words: Rubber seed, Cyanogenic glucoside estimation.

\section{INTRODUCTION}

The cyanogenic glucosides of cassava (mainly linamarin) have been reliably and reproducibly estimated using an exogenous enzyme (linamarase) assay for almost two decades. ${ }^{1,2}$ Rubber seed has the same cyanogenic glucoside ${ }^{3,4}$ but previous work with this material had either used trichloroacetic acid as a cyanide liberator ${ }^{3}$ or yielded very variable results with autolysis. ${ }^{4}$ This study is an attempt to understand the lack of reproducibility in total cyanide determinations and to validate the techniques used previously to estimate total cyanide content in rubber seed.

\section{METHODS AND MATERIALS}

Details are given in the legends of tables.

\section{RESULTS AND DISCUSSION}

\section{Sampling :}

Collection of random samples of rubber seed and analysis by the autolysis technique ${ }^{5}$ yielded total cyanide content varying from $100-4000 \mathrm{mgkg}^{-1}$. These variations can be attributed to (i) inherent differences in the sample and (ii) experimental error. Differences in the sample may be due to among others (a) genetic variation (b) effect of maturity and (c) the history of seeds after seed fall. 
To limit such variations samples seeds were collected from the same field one day after seed fall. Results from six such samples gave 1512, 1177, 2214, 2072, 2176 and $1763 \mathrm{mgkg}^{-1}$ respectively i.e. $1819 \pm 414$ (mean \pm standard deviation). Analysis of seeds from the same fruit collected from a tree gave surprisingly wide disparities (Table 1), indicating that in addition to the factors listed above, other factors possibly affecting the cyanophoric system such as autolytic cyanide release, could be operating even while the fruit is still on the tree. To an analyst this has serious implications especially since rubber has a relatively large seed and therefore might require a relatively large sample weight if variations were to be averaged out to give an analytically significant result. However analysis of large samples present other problems, viz., loss of cyanide during handling (experimental errors) due to the seed having large quantities of cyanide liberating enzymes. ${ }^{5}$

Table 1: Variation of total cyanide in the seeds of the same fruit

\begin{tabular}{|c|c|}
\hline Sample No. & Total Cyanide (mg/kg on dry basis) \\
\hline Fruit 1 & 1897 \\
& 1754 \\
& 15 \\
\hline Fruit 2 & 484 \\
& 609 \\
& 670 \\
\hline Fruit 3 & 2055 \\
& 1592 \\
& 1713 \\
\hline Fruit 4 & 2306 \\
& 2240 \\
& 1885 \\
\hline Fruit 5 & 1905 \\
& 1458 \\
& 231 \\
\hline Fruit 6 & 1199 \\
& 1621 \\
& 1918 \\
\hline
\end{tabular}

Fruits (trilocular) No's 1 to 6 were collected from the tree and each of the three seeds analysed separately. 5 Total cyanide was determined by the picrate method 2,7 in individual seeds of the same fruit by homogenization and autolysis ${ }^{5}(24 \mathrm{~h})$.

In practice it has been found that least deviations were obtained by using $6-8 \mathrm{~g}$ samples at $0-5^{\circ} \mathrm{C}$ while minimising handling time. However a coefficient of variation of $15-25 \%$ can yet be observed. 
Hydrolysis of cyanogenic glucosides

When trichloroacetic acid was used, release was less than $3 \%$ of the available total cyanide. Results obtained previously using this method are therefore grossly misleading. ${ }^{3}$ Use of $2 \mathrm{M} \mathrm{H}_{2} \mathrm{SO}_{4}$ at room temperature also released very little cyanide. This acid required $30 \mathrm{~h}$ refluxing to completely release total cyanide from rubber seed. These experiments also show that low yields obtained with short reflux times did not reflect a hydrolysis of the $\mathrm{C} \equiv \mathrm{N}$ triple bond as previously theorized ${ }^{6}$ as the full complement of total cyanide could be released from this reaction mixture by the action of added linamarase (exogenous) after pH adjustment (Table 2).

Table 2: Total cyanide in rubber seed kernel and meal determined by acid hydrolysis followed by exogenous enzyme hydrolysis

\begin{tabular}{|l|c|c|}
\hline \multirow{2}{*}{ Type of sample } & \multicolumn{2}{|c|}{ Total cyanide (mg/kg on dry basis) } \\
\cline { 2 - 3 } & Acid hydrolysis (i) & $\begin{array}{c}\text { Exogenous enzyme hydrolysis } \\
\text { after (i) }\end{array}$ \\
\hline Immature Kernel & 169 & 12,363 \\
\hline Mature kernel & 22 & 1546 \\
\hline Mature kernel & 32 & 2032 \\
\hline Mature kernel & 69 & 2404 \\
\hline Meal & 20 & 213 \\
\hline
\end{tabular}

Acid hydrolysis 1 was carried out at room temperature $\left(30^{\circ} \mathrm{C}\right)$ and the reaction mixture distilled. ${ }^{6}$ The residue from distillation was adjusted to pH $6(10 \mathrm{ml}$ of $0.1 \mathrm{M}$ phosphate buffer) and Incubated with linamarase ${ }^{2}$ (EC 3.2.1.21) for $4 \mathrm{~h}$ and cyanide estimated.

Two hours of autolysis was sufficient to completely release total cyanide. Longer autolysis times could be used for release, provided cyanide utilizing systems (e.g. rhodanese) are not active. Results of this study show that $24 \mathrm{~h}$ incubation at ambient temperature resulted in a loss of approximately $10 \%$ cyanide (Table 3 ).

Addition of exogenous linamarase to the distilled autolysate residue did not yield significant additional cyanide in processed material like rubber seed meal, indicating that the activity of endogenous enzyme was adequate for the release of cyanide even after processing. 
Table 3: Cyanide utilization during incubation period

\begin{tabular}{|c|c|c|}
\hline Incubation time (h) & $\begin{array}{c}\text { Total cyanide recovered } \\
(\mathrm{mg})\end{array}$ & Cyanide utilized (\%) \\
\hline 0 & 320 & 0 \\
\hline 2 & 310 & 3 \\
\hline 4 & 295 & 8 \\
\hline 24 & 284 & 11 \\
\hline 48 & 281 & 12 \\
\hline
\end{tabular}

A sample of extract was prepared by homogenizing rubber seed kernel $(60 \mathrm{~g})$ in water $(600 \mathrm{ml}) . \mathrm{CO}_{2}$ was passed through the nitrate until all cyanide was removed (4h). The solution was made up to 1 I and KCN $(0.4 \mathrm{~g})$ was introduced. Samples were incubated separately and cyanide content determined over $48 \mathrm{~h}$.

\section{Acknowledgement}

The authors thank the Natural Resources, Energy and Science Authority (NARESA) for grant RG 88/C/04. This work is a part of the M.Phil. thesis submitted to the, University of Sri Jayewardenepura by G.V. Mallika.

\section{References}

1. Pieris N.M. (1976). Studies on the cyanogenic glucosides of Manihot esculenta Crantz. Ph.D Thesis. University of Colombo.

2. Pieris N. M. M., Jansz E. R. \& Kandage R. (1974). Cyanogenic glucoside content of manioc. Joumal of the National Science Council of Sri Lanka 2: 67-76.

3. UNIDO (1985). Project Document US/GLO/81/103. Phase 1. Development of rubber seed processing technology for the production of vegetable oil and animal feed. Edited by KH Todt and HFT Vogt Institute fir Natürwissenschaftlich Technische Dinstet. Federal Republic of Germany. p. 1-85.

4. UNIDO (1985). Project Document US/GLO/81/103, Phase 11 Rubber seed processing for the production of vegetable oil and animal feed, CISIR, Sri Lanka pp. 121.

5. Mallika G. V. (1991). Applied chemical studies on rubber seed to support its industrial utilization. M.Phil thesis of University of Sri Jayewardenepura.

6. Jansz E. R. \& Nethsingha C. L. M. (1973). Manioc; selected topics. Joumal of the National Science Council of Sri Lanka 1: 83-96.

7. Wood T. (1966). The Isolation, properties and enzymic break down of linamarin from cassava. Joumal of Science, Food and Agriculture 17: 85-91. 